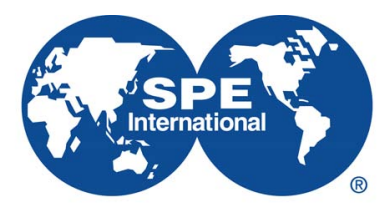

Society of Petroleum Engineers

\title{
SPE-189018-MS
}

\section{Outcrop Analogue Study of Deformation Bands and Their Impact on Rock Properties of the Productive Series in South Caspian Basin}

\author{
Gasham Zeynalov, Shahriyar Alkhasli, and Aydin Shahtakhtinskiy, Khazar University eiLink Research \& \\ Development Center \\ Copyright 2017, Society of Petroleum Engineers \\ This paper was prepared for presentation at the SPE Annual Caspian Technical Conference and Exhibition held in Baku, Azerbaijan, 1-3 November 2017.
}

This paper was selected for presentation by an SPE program committee following review of information contained in an abstract submitted by the author(s). Contents of the paper have not been reviewed by the Society of Petroleum Engineers and are subject to correction by the author(s). The material does not necessarily reflect any position of the Society of Petroleum Engineers, its officers, or members. Electronic reproduction, distribution, or storage of any part of this paper without the written consent of the Society of Petroleum Engineers is prohibited. Permission to reproduce in print is restricted to an abstract of not more than 300 words; illustrations may not be copied. The abstract must contain conspicuous acknowledgment of SPE copyright.

\section{Abstract}

South Caspian basin (Azerbaijan) is the principal place of hydrocarbon accumulation in Productive Series sandstone reservoirs. The basin was complicated by total sub-meridional contraction as a result of north-east compressional deformation which caused generation of deformation bands in various rock types of plunging anticlines with significant influence regarding rock properties. The objective of the study is quantitative estimation of deformation bands impact on rock properties based on field measurements held in Yasamal Valley outcrops in northern-west part of the South Caspian basin and integration of acquired data to analogue steeply dipping reservoir rocks of South Caspian basin.

Geological factors as lithological, structural and petrophysical elements are controlling deterioration or potential enhancement of the rock properties in the South Caspian basin with high concentration of deformation bands. Natural gamma radioactivity, permeability, dips and strikes measurements across wide range of facies were integrated for understanding the impact of these factors. Outcrop plugs with and without deformation bands were tested for Routine and Special Core Analyses, petrographical description, SEM, $\mathrm{XRD}$ and $\mathrm{CT}$ scan tests to estimate the rock properties at the pore scale.

Field gamma ray measurements analysis reveal that no deformation bands are expected in the rocks with shale volume higher than $32 \%$. Furthermore, probability function of deformation bands occurrence has exponentially declining nature. Higher concentration of deformation bands was observed in the northern part of the Yasamal Valley, where larger volume of iron- bearing calcite-cement precipitation during burial diagenesis has taken place and caused reduction in porosity and permeability. These calcite cements were precipitated in channelized sandstone deposition system and most of them are localized in tabular concretions which generally follow the bedding but, in some cases, terminate within a bed across facies. High amount of calcite cement caused greater impact of deformation bands. The intensity of rock degradation is dictated by mineralogical composition and texture properties. In comparison to the host rock plugs taken from the outcrop, adjacent samples with a single deformation band show 33\% and 3\% decrease in permeability and porosity, respectively. Dip and dip gradient in sandstone beds do not reveal an obvious impact on deformation bands distribution.

Large volume of calcite cement precipitation was observed in Balakhany reservoirs in north-east limb of the Yasamal Valley which caused greater impact deformation bands and reduction in permeability. Isotopic 
analysis is recommended to be performed for interpretation of the calcite cement origin and the timing of its precipitation. Impact of deformation bands on permeability can be measured at a plug scale, macro scale estimates would require either whole core flooding or numerical modeling.

\section{Introduction}

Petrophysical properties of deformed rocks in comparison to non-degraded have been extensively questioned. One of the common structural features that represent deformed rocks is deformation bands (DB), which occur in brittle porous granular media. Aydin (1978) witnessed them in sandstones as millimeterto centimeter-thick faults with low displacement, which are formed by fracturing and further coalition of grains. The cohesiveness of these tabular structures reduces porosity and permeability in contrast with the adjacent host rock and induces anisotropy, hence creating a potential barrier/baffle to fluid flow in clastic reservoirs (Fossen and Bale, 2007). The small dimensions of DB restrict their detection from seismic data and conventional well logs, although higher resolution image logs could help with this limitation. Deformation bands have been observed in subsurface cores but considering their limited availability and spatial constraints, analogous outcrops serve as the most convenient recourse for studying these features.

This paper is concerned with quantifying formation conditions and distribution of deformation bands and their field-wide and local impact on the Lower Pliocene Productive Series reservoir rock properties in the South Caspian Basin, which is the principal place of hydrocarbon accumulation in these sandstone reservoirs. Sediments of the Productive Series are exposed extensively over the Absheron Peninsula in the north-western coast of the South Caspian Basin and are considered to be good reservoir analogues for offshore fields of the basin (Reynolds et al., 1998). This basin was complicated by regional submeridional contraction as a result of north-south oriented compressional deformation (Jackson \& McKenzie, 1984; Jackson et al, 2002; Allen et al., 2003) which generated deformation bands in steeply dipping sediments of the Productive Series in plunging anticlines.

The circumstances that lead to generation of DB depend on external factors (e.g. burial depth, tectonic regime) and various intrinsic rock properties such as mineralogy, consolidation, grain size, grain morphology and sorting, etc. (Schultz and Siddharthan, 2005; Fossen et al., 2007). These parameters dictate possibility of DB creation, deformation mechanism and resultant DB type with specific petrophysical properties and grain crushing (cataclasis) intensity. Ballas et al. (2015) suggested that the former factors show a clearer effect on porosity and permeability, while impact of the latter is less observable.

Mineralogical composition of sandstones is paid significant attention in our study as each mineral type has its own elastic properties (e.g. hardness), which control their resistance to deformation. We observe an increased number of DB in calcite-rich sandstones opposed to unconsolidated clean sandstones, which comes from weaker nature of calcite concretions than quartz grains. While calcite concretions favor DB formation, ductile clay minerals tend to cease their occurrence, as seen from decreasing concentration of DB with greater volume of shale in sandstones. Moreover, calcite and clay fractions in sandstones impact porosity and permeability differently than DB.

Another important factor controlling formation and distribution of DB is bed geometry. We observe an increasing trend between layer dips and average number of DB per meter, since a rise in dip angles is considered as indication of intensified stress scale. Similar relationships were witnessed by Zuluaga et al. (2012) and Ronnevik (2013). Additionally, we think that bed curvature (i.e. change in dip/strike along and across layers) controls DB occurrence, however this approach is out of the scope of current study.

Impact of deformation bands on fluid flow can be considered as a function of their kinematics and petrophysical properties such as porosity and permeability, which are parameters of the highest interest of any deformation band types. Based on integrated analysis of several studies, Ballas et al. (2015) revealed that permeability reduction of an individual deformation band ranges from zero to six orders of magnitude compared to the parent rock. Fossen et al. (2007) evaluated reduction in flow efficiency based on the 
differential form of steady-state Darcy equation and concluded that permeability difference between the host rock and deformation band should be higher than four orders of magnitude to have a significant effect on fluid flow.

In this paper, we will discuss reservoir and pore scale effects of DB on rock properties. The small dimensions of DB also limit direct measurements of their properties using Routine Core Analysis (RCAL) or Mercury Injection Capillary Pressure (MICP) experiments. While there are several complex computational methods for estimation of single DB permeability, within the reach of our study we used a simple harmonic averaging methodology to evaluate permeability contrast.

To meet all of the study objectives mentioned above we investigated outcrops of several representative structures in the Absheron Peninsula, including Yasamal Valley (composed of Shubany and Shabandag fields), Lokbatan, Puta-Kushkhana, Kergez- Kiziltepe and Shongar fields (Fig. 1). Among these fields, Yasamal Valley has been chosen as the main area of research due to the excellent exposure of the Productive Series and distribution of deformation bands in the area of the south-southeast plunging anticline hinge.

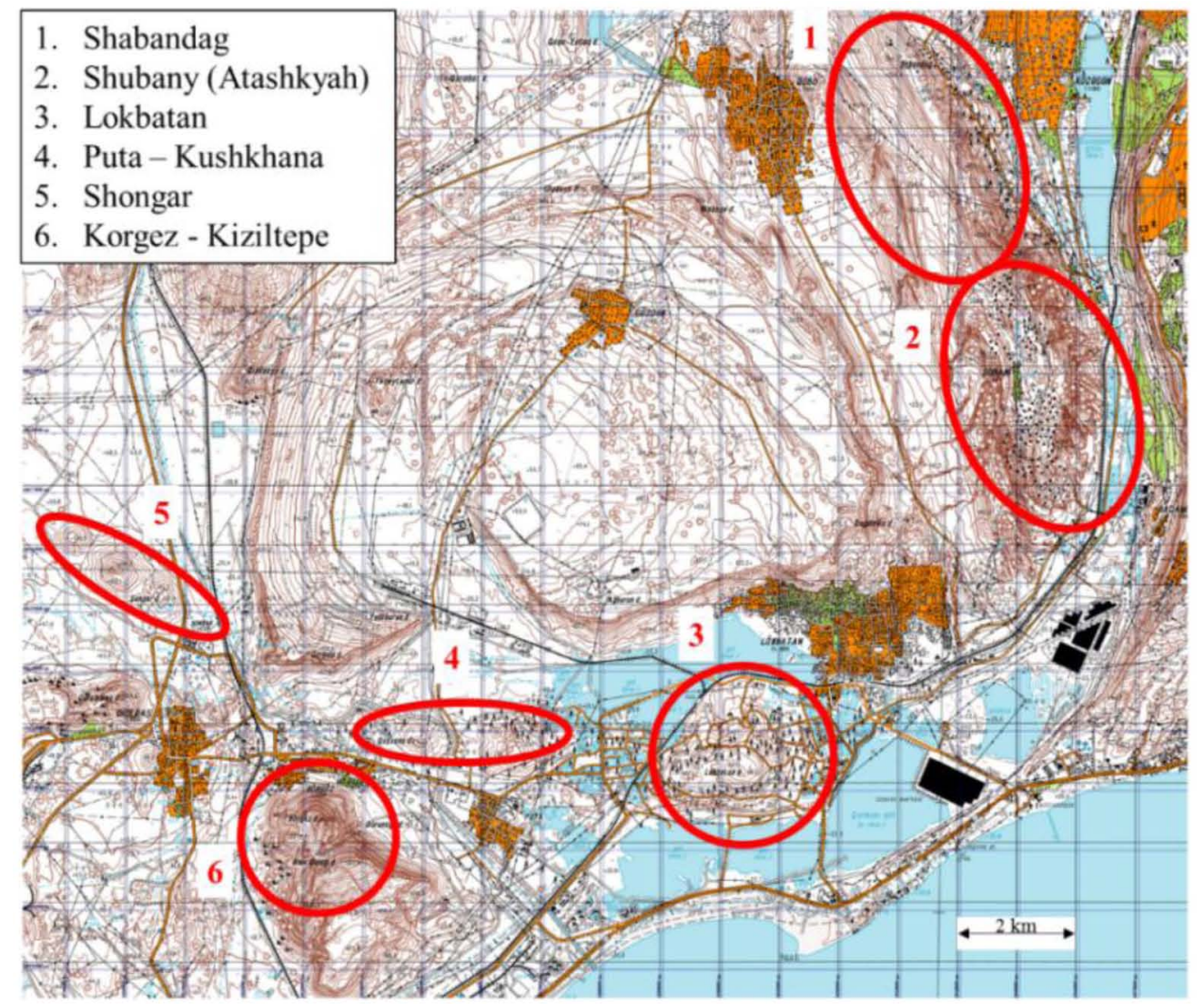

Note: Identification of the structures was based on map of Yusifzade et. al (oil \& gas fields map, 1986)

Figure 1-Topographic map of the area under investigation with highlighted structures

DB were studied through integrated analysis of field measurements of natural radioactivity and onsite permeability of rocks and complex laboratory tests. The next chapter gives detailed insight on geology of the investigated area, followed by methodology, results and discussions of the acquired data, and the conclusions of the study. 


\section{Geological Setting}

\section{Structure}

The South Caspian Basin (SCB) is located in the southern deepwater part of the Caspian Sea, bounded by the West Turkmenistan basin in the east and the Kura basin in the west, and regionally lies at the northern side of the Arabia-Eurasia collision zone (Fig. 2.1). The basin has a basement surface of oceanic crust, overlain by about $20 \mathrm{~km}$ of sediments. Its age and original tectonic setting are not certain (Brunet et al., 2003), however it is likely that the basin originated as a back-arc basin between the Jurassic (Zonenshain and Le Pichon, 1986) and the Paleogene (Allen et al., 2004) periods. Most of the sedimentary rocks in the SCB were deposited after the closure of Neotethys via collision of Arabia with Eurasia in the Middle Eocene (Hempton, 1987).

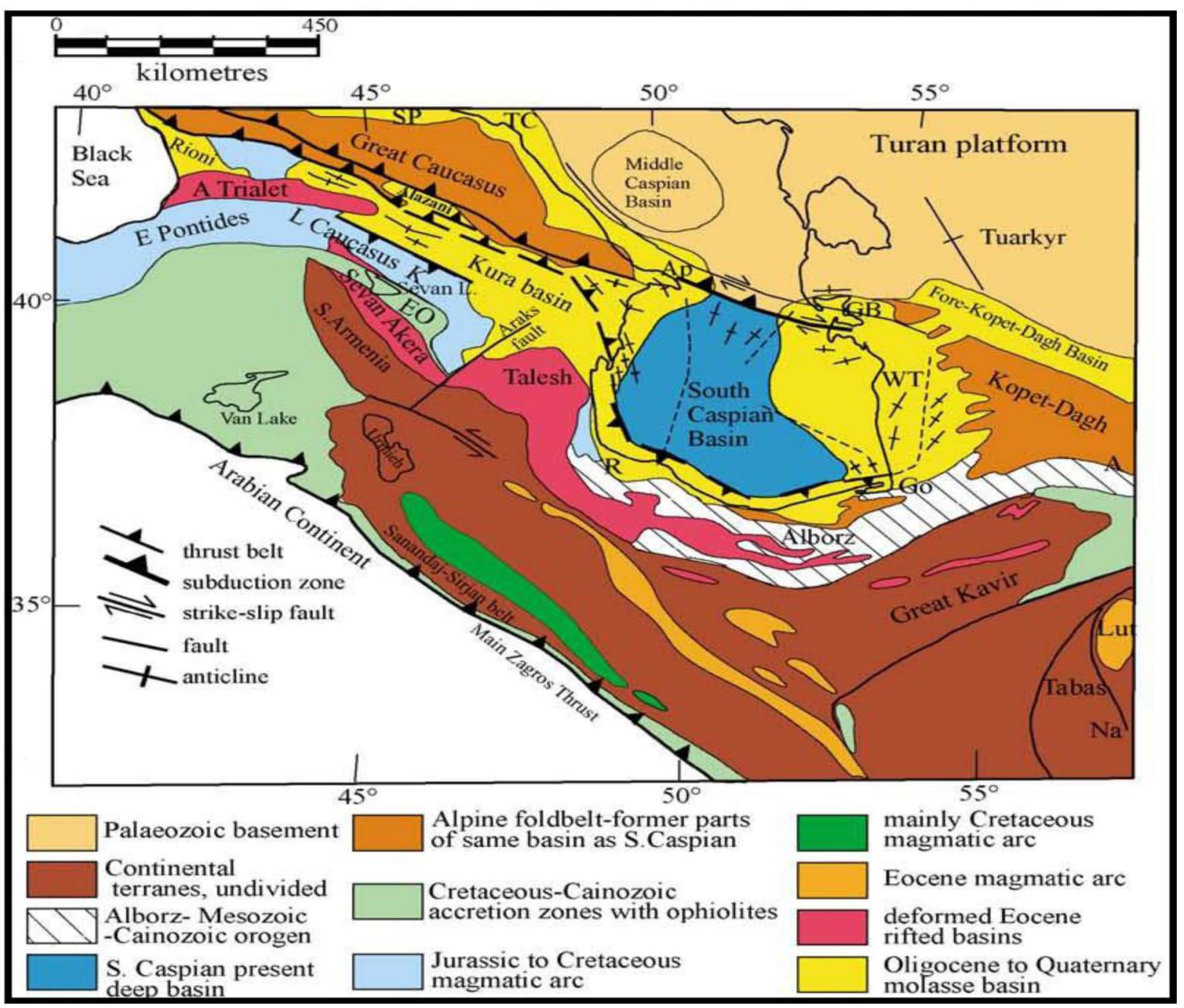

Figure 2.1-General geologic map of the South Caspian area showing the main tectonic units. A: Aghdarband; Ap: Apsheron; ATrialet: Achara-Trialet; EO: Erevan-Ordubad; E Pontides: Eastern Pontides; GB: Great Balkhan; Go: Gorgan; K: Karabakh; L Caucasus: Lesser Caucasus; Na: Nayband; R: Rasht; SP: Scythian platform; TC: Terek-Caspian basin; WT: Western Turkmenia. (Brunet et al., 2002)

From the late Miocene to Pleistocene the compressional deformation has intensified by NNE-SSW oriented convergence between the Arabian and stable Eurasian plates, generating fold and thrust belts of the Greater and Lesser Caucasus and spanning to the east, covering the Caspian Sea region from the Absheron peninsula on the western to the Kopetdagh on the eastern coasts (Jackson and McKenzie, 1984; Jackson 
et al, 2002; Allen et al. 2003; Golonka, 2004; Nemcok et al., 2011). The mentioned convergence process affected the South Caspian region during the Pliocene-Pleistocene times (Allen et al.2004) and consequently caused deformation of the Productive Series (Lower Pliocene) in steeply dipping anticline folds, strongly influencing the petrophysical properties of the reservoirs.

Anticline fold systems in the basin have a variety of orientations and structural styles. Among the folds complicated with deformation bands, Yasamal Valley located in the Absheron Peninsula (Fig 2.2) is of particular interest, where the Upper Productive Series (Balakhany to Sabunchy Suites) are widely exposed with favorable conditions for studying DB.

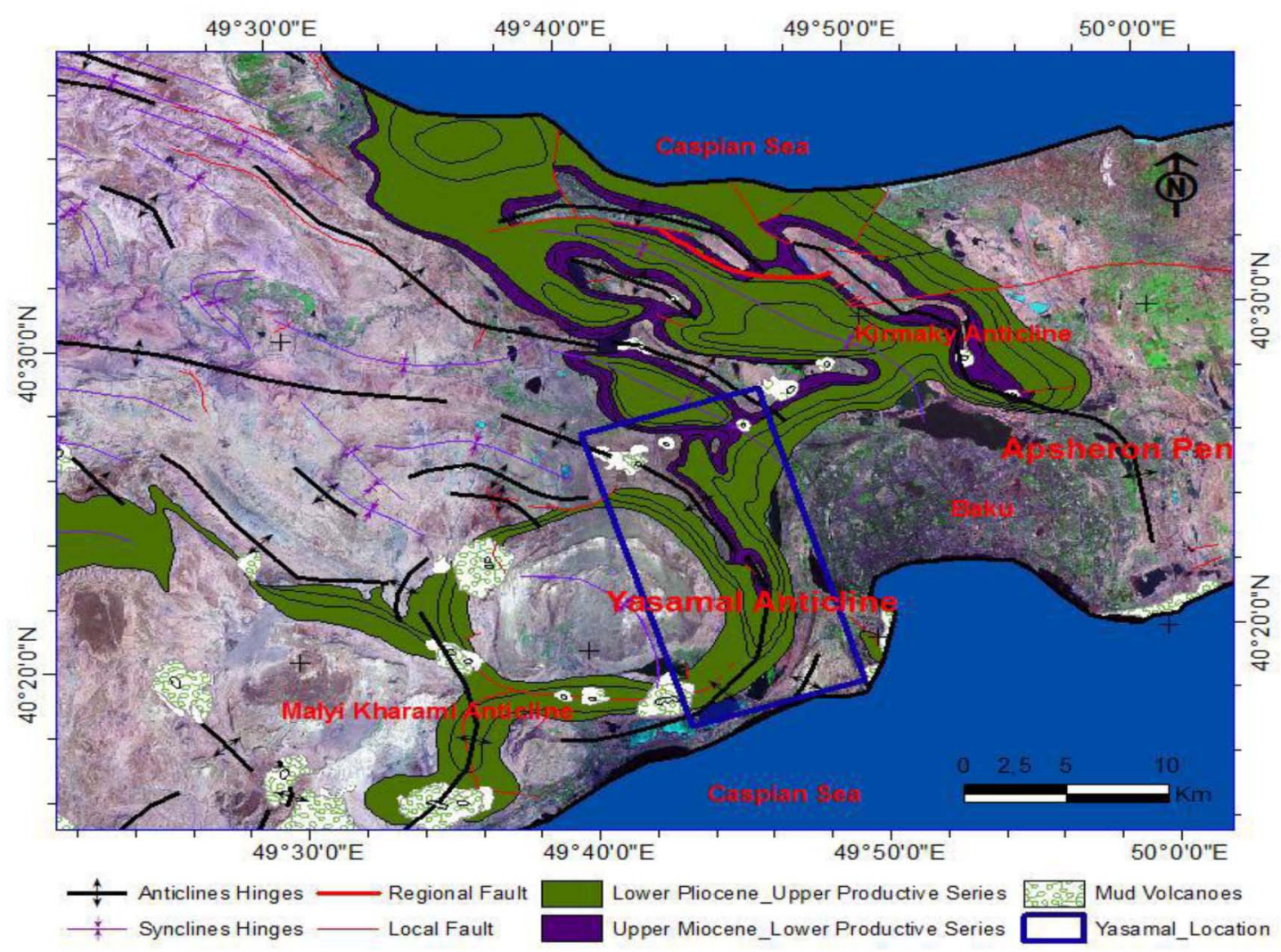

Figure 2.2-Simplified geological map of Absheron Peninsula (Alburki, 2015)

The Yasamal anticline (Fig. 2.3) was formed as a result of folding of the late Pliocene sediments (Gurevich and Chilingar, 1995). Outcrops of the Balakhany and Sabunchy subunits are exposed in the area of the southsoutheast plunging anticline hinge and are highly valuable as analogues for hydrocarbon accumulations in the South Caspian basin.

This anticline is complicated by three longitudinal faults at the crest - one of which is a thrust fault (Alizadeh et al., 1966; Allen et al., 2003), possibly caused by overturning of the east limb of the structure and by series of latitudinal normal and reverse faults, some of which are depicted in Fig. 2.3. The structure is asymmetric, with the west limb dipping at around 40 degrees, and the east limb dipping at near-vertical position with around 80-90 degrees. Overturned layering of the east limb is observed along the entire flank. As it can be seen in Fig. 2.4, the layers at the eastern limb are slightly declined from vertical position and are dipping towards the West. Our field measurements were performed in three locations: the south pericline $(\log 1)$ and southern $(\log 2)$ and northern $(\log 3)$ parts of the east limb, where deformation bands are abundant (see Logs in Fig. 2.3). 


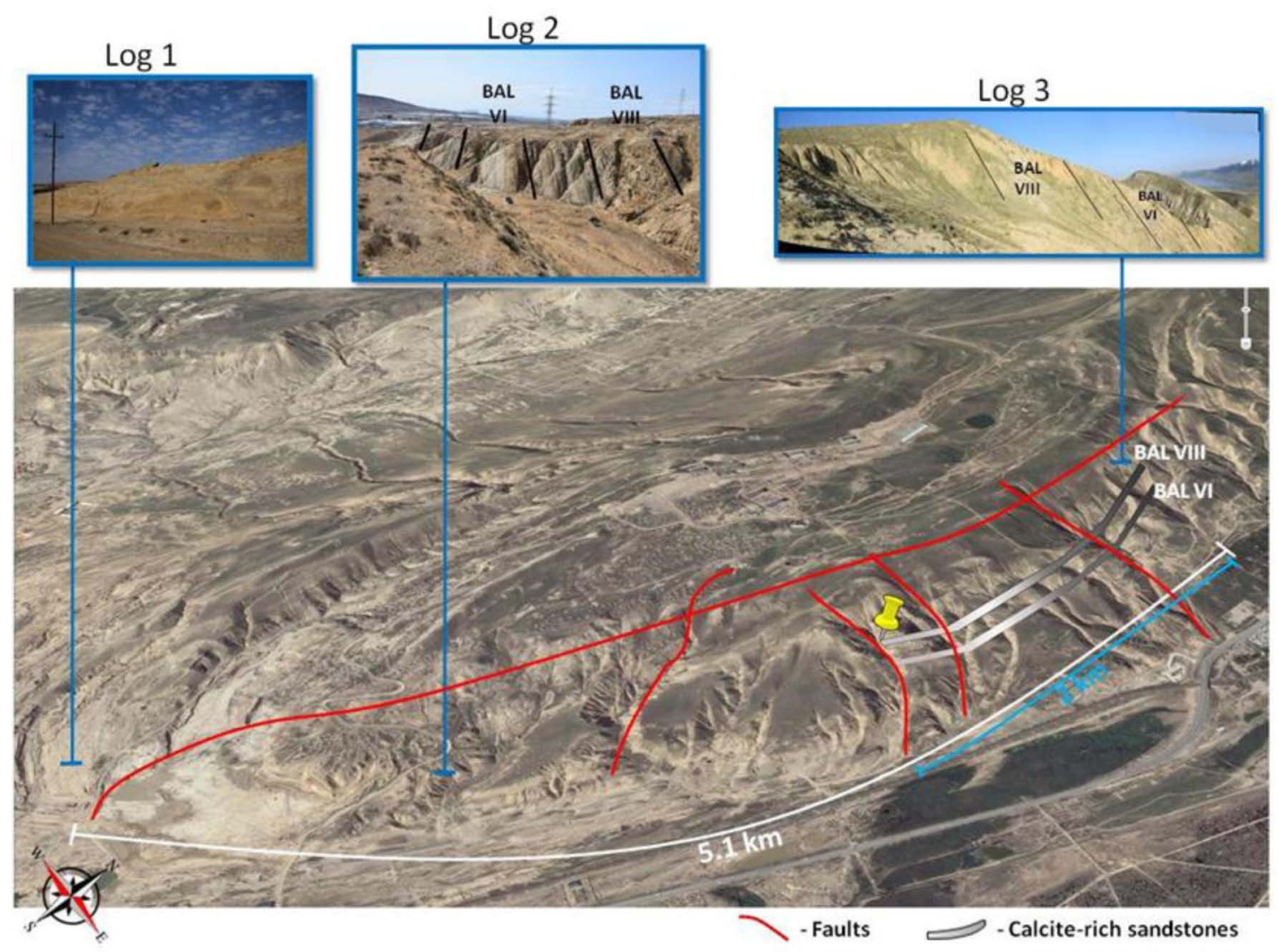

Figure 2.3-Satellite image of Yasamal (Shubany) anticline, showing locations of logs (dark blue), faults (red) and distribution of calcite-rich layers (light-blue)

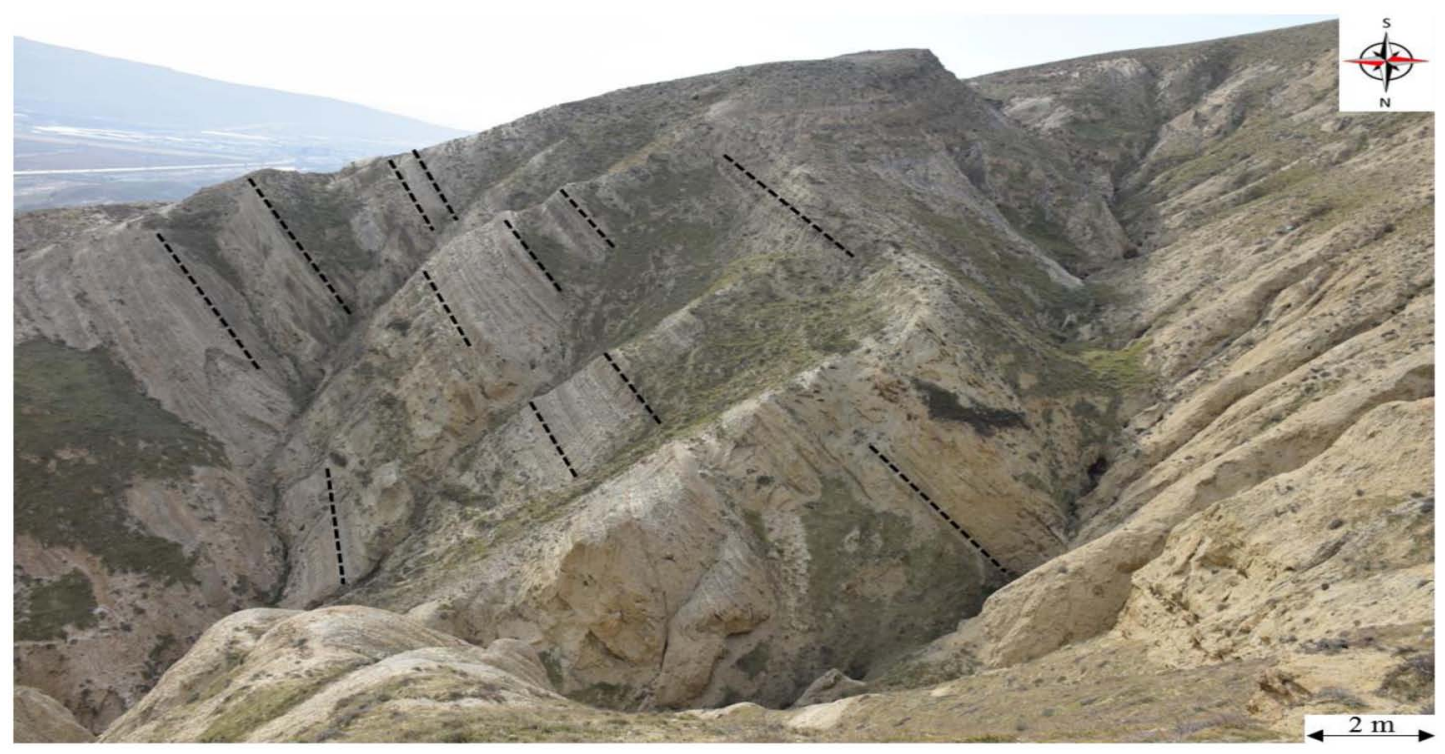

Figure 2.4-Outcrop of overturned layers in the east limb of Yasamal anticline

\section{Stratigraphy}

The Productive Series of the Absheron Peninsula is conventionally subdivided into nine suites (equivalent to formations) based on their lithological and facial characteristics (Jones and Simmons, 1996). Stratigraphy of exposed Productive Series in Yasamal Valley has been under investigation for the last few decades. Various interpretations exist on division of subunits. One of the latest modifications is summarized in Fig. 2.5 a. As 
of now, outcrop subunits cannot be accurately correlated to those of the subsurface due to the absence of an independent biostratigraphic scheme (Reynolds et al., 1998).
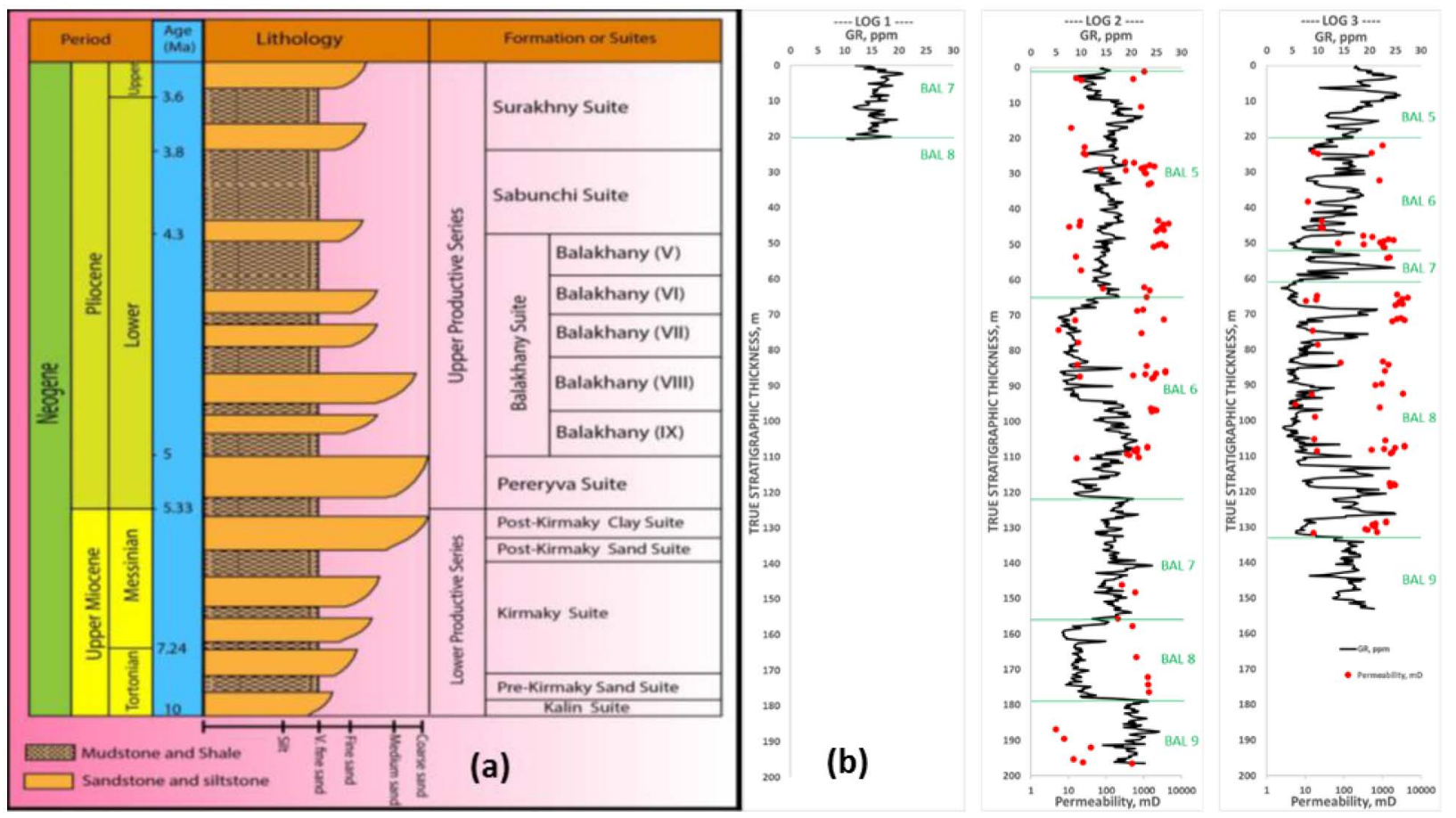

Figure 2.5-a) Stratigraphic column of the Productive Series at Yasamal Valley summarizing the vertical changes in lithology through the series (modified after Devlin et al., 1999); b) Gamma Ray logs of Balakhany Suite sandstones measured at Yasamal Valley

The Balakhany Suite subunits IX, VIII, VII, VI and V are exposed at Yasamal Valley. These subunits were assigned by us based on vertical changes in the proportion of sandstones and mudstones (Fig. 2.6) and assisted with GR logs (Fig. 2.5 b), measured during the fieldwork.

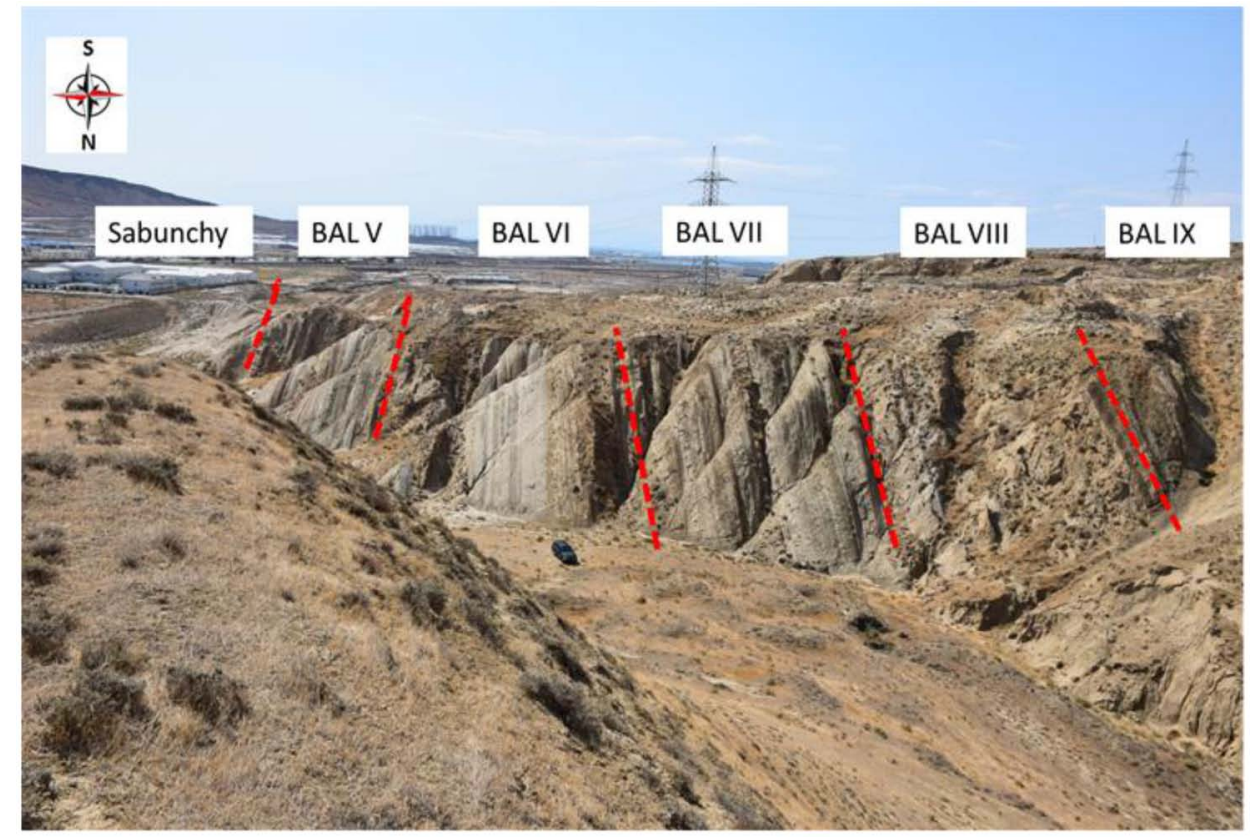

Figure 2.6-Schematic division of Balakhany Suite in Yasamal Valley 
Facies were described during logging and summary on geological description of Balakhany subunits is provided below:

Balakhany $\mathbf{V}$ represents $56 \mathrm{~m}$-thick silt-rich formations. Its base is taken at a change in facies from an underlying thick sandstone package of subunit VI. This subunit represents a delta front depositional system with heterolithic mixture of coarsegrained channelized sandstone and mudstone and siltstone. The coarsening-upward package is clearly observed. Its upper part is bordered by a prominent, laterally continuous grey mudstone layer of the overlying Sabunchy Suite.

Balakhany VI is presented by a 50m-thick relatively sand-prone formation. Several large amalgamated medium-grained sand and fine-grained sandstone packages formed depositional strike-oriented exposure. Sedimentary structures display low-angle trough cross-bedding which commonly pass upwards to current ripple lamination in south part, and sheet-like tabular crossbedding lamination in yellowish-grey sand in north part of the East Limb area.

Balakhany VII is composed of approximately 40m-thick mudstone-prone heterolithic facies. Planarbased, fine-grained channelized sandstone packages display through cross-bedding. They are interstratified with weakly developed, coarsening upward, mudstone to silty-sandstone and sandstone packages, comprised of amalgamated, tabular beds of convolute.

Balakhany VIII is composed of a 37m-thick exposure of brown-grey and yellowish-grey amalgamated medium-grained sand and fine-grained sandstone and relatively few heterolithic mudstone intervals interbedded within the sandstone sheets Amalgamated channel sands form a multilateral sheet sand complex with minor preservation of overbank mudstones and claystones. High volume of calcite cement is distributed along the East Limb of the anticline, starting from the north end of the structure and extending for about $2 \mathrm{~km}$ towards the south. Rare calcite cementation, forming only isolated circles, is observed in southern part of the East Limb. Sedimentary structures of Balakhany VIII are represented by small-scale trough crossbedding, tabular cross-bedding in some places and large-scale convolute bedding.

Balakhany IX is characterized by partially exposed $25 \mathrm{~m}$-thick sediments and is composed of a heterolithic mixture of brown- grey mudstone, yellowish-grey siltstone and sheet like channelized sandstone as laterally continuous floodplain deposits. The exposed lower part of Balakhany IX is presented by relatively coarser grained unit. Planar based, tabular cross-bedding sandstones and siltstones commonly display small-scale climbing ripple and convolute lamination.

Correlation of channelized system becomes challenging due to the discontinuous nature of layers (Fig 2.5. b). This led to differences in true stratigraphic thicknesses (TST) between second and third logs. Moreover, there is a possibility that faults depicted in Fig. 2.3 influence variation in TST. Nevertheless, general tendency for net-to-gross of Balakhany subunits remains similar.

\section{Depositional Environment}

The Productive Series, as the main reservoir rock in the SCB, was deposited in fluvial, lacustrine and deltaic settings, transported by different drainage systems: Paleo-Volga, Paleo-Amu Darya, and Paleo-Kura rivers (Fig. 2.7) after isolation of the South Caspian basin from the global ocean in the latest Miocene (Morton et al, 2003; Hinds et al., 2004; Aliyeva, 2005; Green et al., 2009; Jones and Simmons, 1996; Reynolds et al.,1998; Devlin et., 1999). 


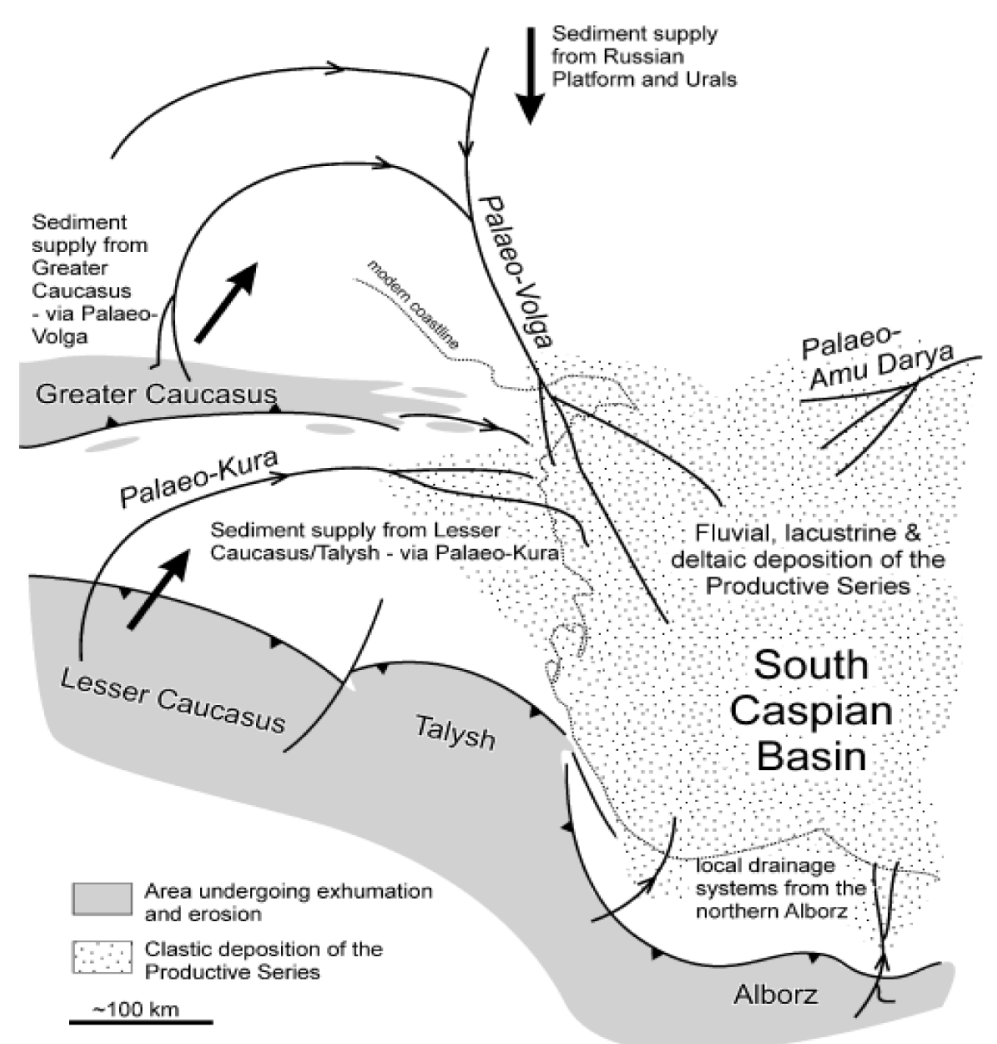

Figure 2.7-Sketch of drainage systems during deposition of largely the Lower Pliocene Productive Series (Morton et al., 2003)

Study of depositional environment of Yasamal during the Upper Productive Series (mainly Balakhany time) with relevance to deformation bands is important as changes in depositional environment can result in variations in mineralogy and petrography of rocks, which can, in turn, cause different mechanisms and intensity of deformation bands formation.

Outcrop observations in logs reveal two well exposed sandstone subunits: the thicker and coarsergrained sandstone outcrops of Balakhany VIII, and the thinner-bedded and finer-grained sandstone outcrops of Balakhany VI. These sandstone-prone settings (Balakhany VIII \& VI) are interpreted as deposition during periods of increased fluvial-deltaic discharge and sediment supply, while mudstone-prone settings (Balakhany IX, VII, V), in contrast, are interpreted as deposition during periods of decreased fluvial-deltaic discharge, and therefore coarse-grained sediments are not observed.

Sand-prone settings mainly consist of amalgamated (massive) and braided fluvial sheet sandstones Mudstone-rich settings are dominated by alluvial plain and lacustrine facies. The succession displays an overall fining-upward trend, which is controlled by long-term climatic cooling, decreased fluvial discharge by tidal processes and reduced coarse clastic material input.

In the south-eastern limb zone of Yasamal anticline Balakhany VIII is composed of amalgamated channel sands of delta front settings, which formed a multilateral unconsolidated sheet sand complex with minor preservation of overbank mudstones and less number of deformation bands than in Balakhany VIII subunit of north-east limb. Fine-grained sand-dominated Balakhany VI is characterized by deposition of a mixture of proximal floodplain and major channel sands in both south-east and north east parts of the limb.

As mentioned earlier, high amount of calcite $(\mathrm{CaCO} 3)$ precipitation was observed in the outcrops of Balakhany Suite fluvial- deltaic sandstones of Yasamal anticline. Calcite is distributed along the east limb of the structure, starting from its northern end and extending for about $2 \mathrm{~km}$ towards the south (refer to Fig. 2.3).

Calcite cements are precipitated in channelized sandstones and most of them are localized in concretions (Fig. 2.8). These tabular concretions generally follow the bedding but, in some cases, terminate within a bed 
across facies. Calcite has partly dissolved in many concretions, probably since being exposed as an outcrop, and hematite has precipitated in the resulting pores. Hematite gives the concretions a reddish and reddishbrown color, easily distinguished from loose sandstones around them.

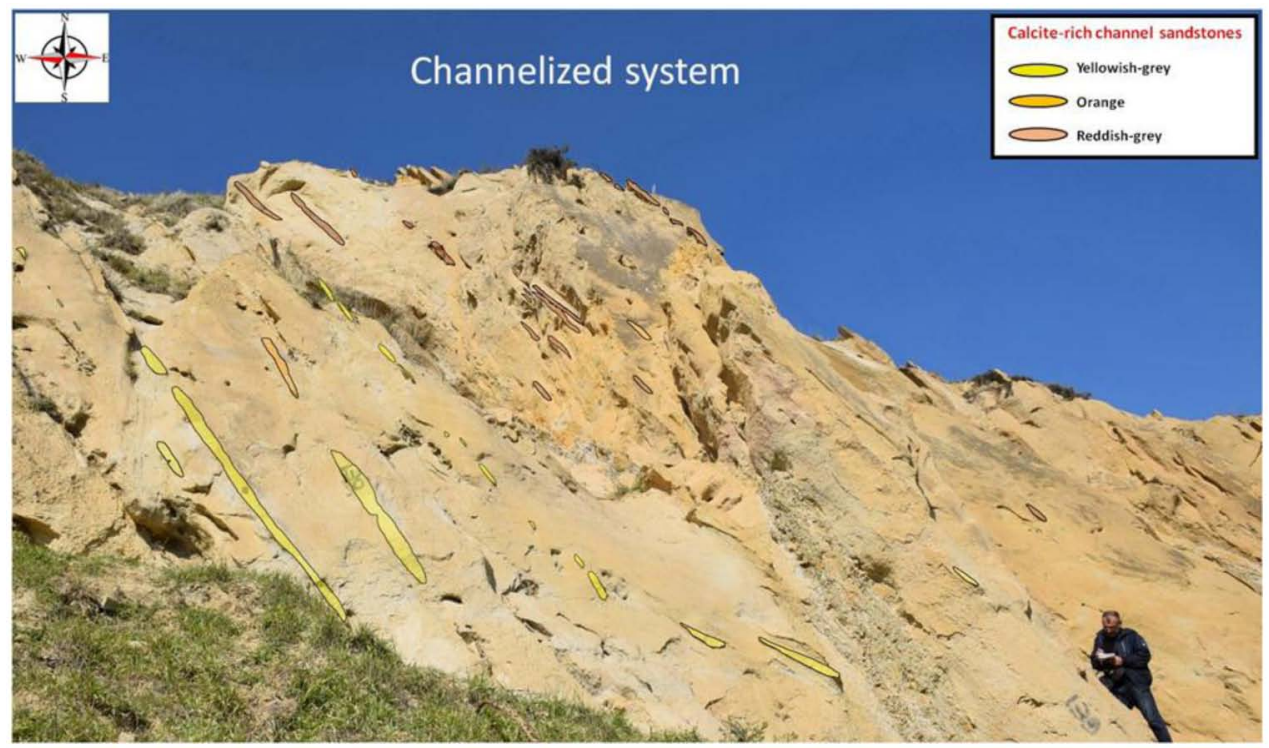

Figure 2.8-Tabular calcite concretions in Bal VIII sandstones observed at the northern part of the east limb of Yasamal anticline.

In summary, the observed sandstones can be classified into two main types: 1) the wide-spread unconsolidated, relatively clean and 2) locally distributed consolidated, calcite-rich. The latter are abundant in $\mathrm{DB}$, displaying complex distribution patterns (Fig. 2.9). XRD data show that these facies have a sharp contrast in mineralogical composition (Fig. 2.10). While the percentage of calcite in unconsolidated sandstones varies between $10 \%$ and $20 \%$, in calcite-rich sandstones it reaches 40 to $50 \%$.

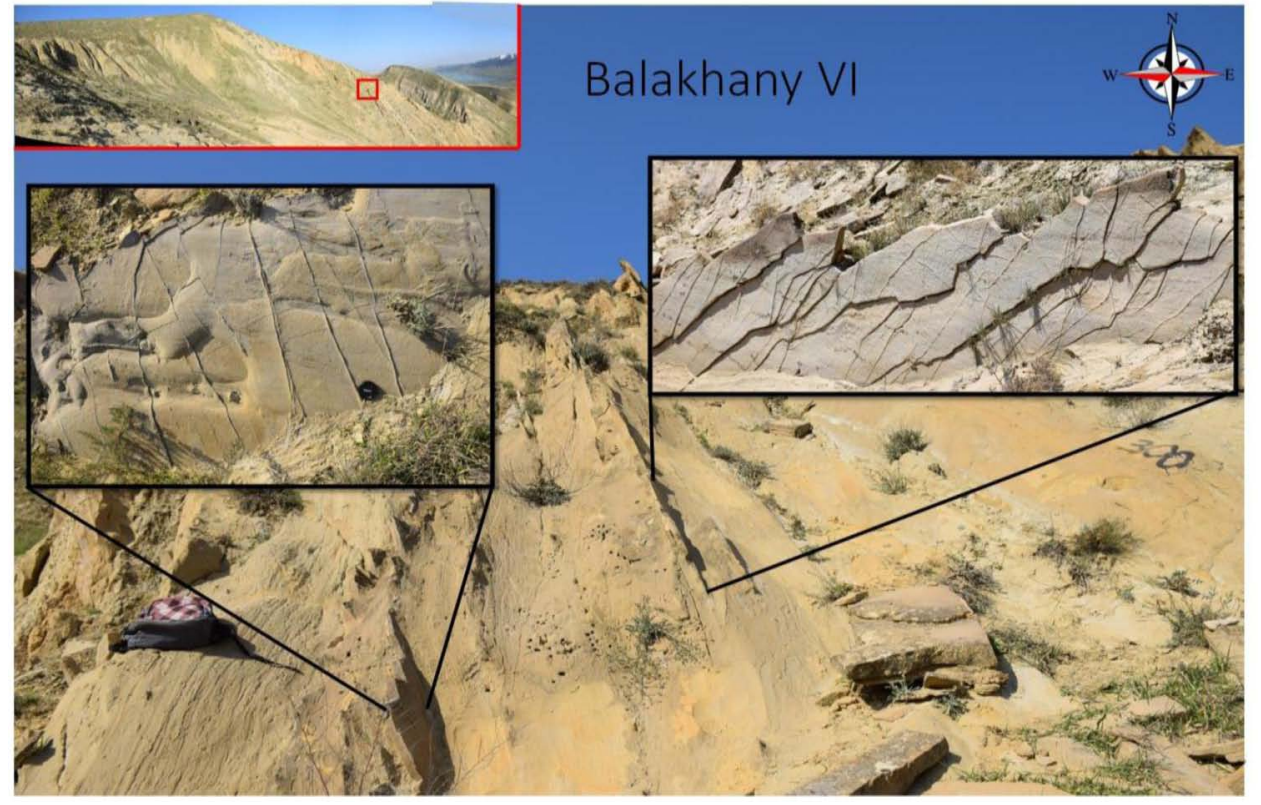

Figure 2.9-Example of calcite-rich sandstone layers of Balakhany VI subunit at the northern part of the east limb of Yasamal anticline. These layers are abundant in deformation bands and fractures with complex patterns. 


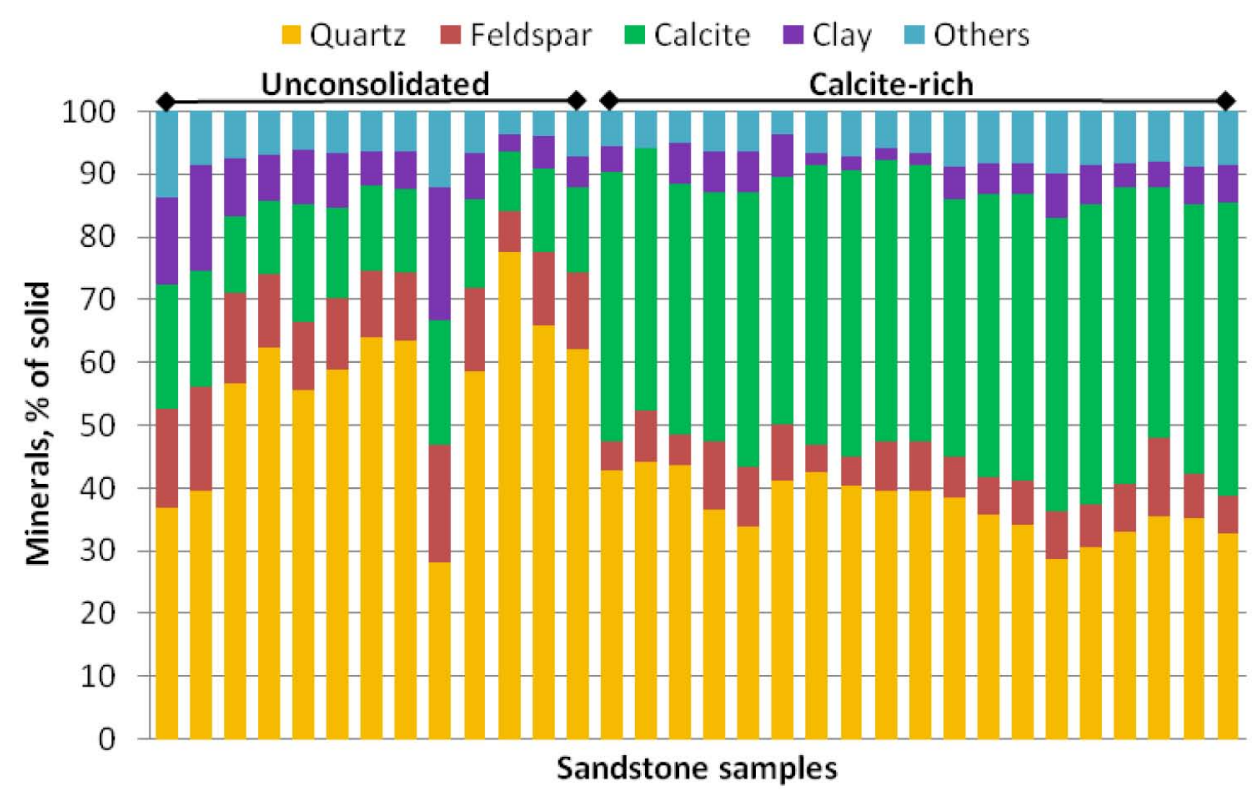

Figure 2.10—XRD-based mineralogy database for Yasamal Valley sandstones

Above-mentioned successions of sandstone and mudstone-shale dominated facies of Balakhany units characterize repeated proximal and distal fluvial, and probable tidal deltaic environments to high frequency base-level fluctuations of Caspian lake, which could have caused the high volume of calcite cement precipitation in channelized sandstone. However precise interpretation of the calcite cement origin and the timing of its precipitation would require isotopic analysis.

\section{Methodology}

The fieldwork was concentrated in the east limb of the plunging Yasamal anticline, where DB were examined in its steeply dipping and overturned layers. To properly characterize occurrence, distribution and impact of DB on the field scale, variety of influencing geological parameters such as bed geometry, mineralogy and net-to-gross were to be captured. For this purpose measurements were performed across sequent stratigraphic units of the Balakhany Suite (Upper Productive Series) using a portable Gamma Ray tool (MGS-150) and Permeameter (Tiny Perm II).

A comprehensive GR log of the Balakhany Suite (see Fig. 2.5 b) was built on the basis of discrete measurements of its natural radioactivity along the true stratigraphic thickness (TST) of the outcropping layers in $30 \mathrm{~cm}$ increments using GR tool (green arrows in Fig. 3.1). As mentioned in the introduction, one of the major study objectives was to relate formation conditions of DB to ductility of sandstones caused by their clay content. To represent field-scale ductility, shale fraction $\left(\mathrm{V}_{\text {shale }}\right)$ was calculated from GR log using Steiber's 1970 empirical equation (Asquith et al., 2014). 


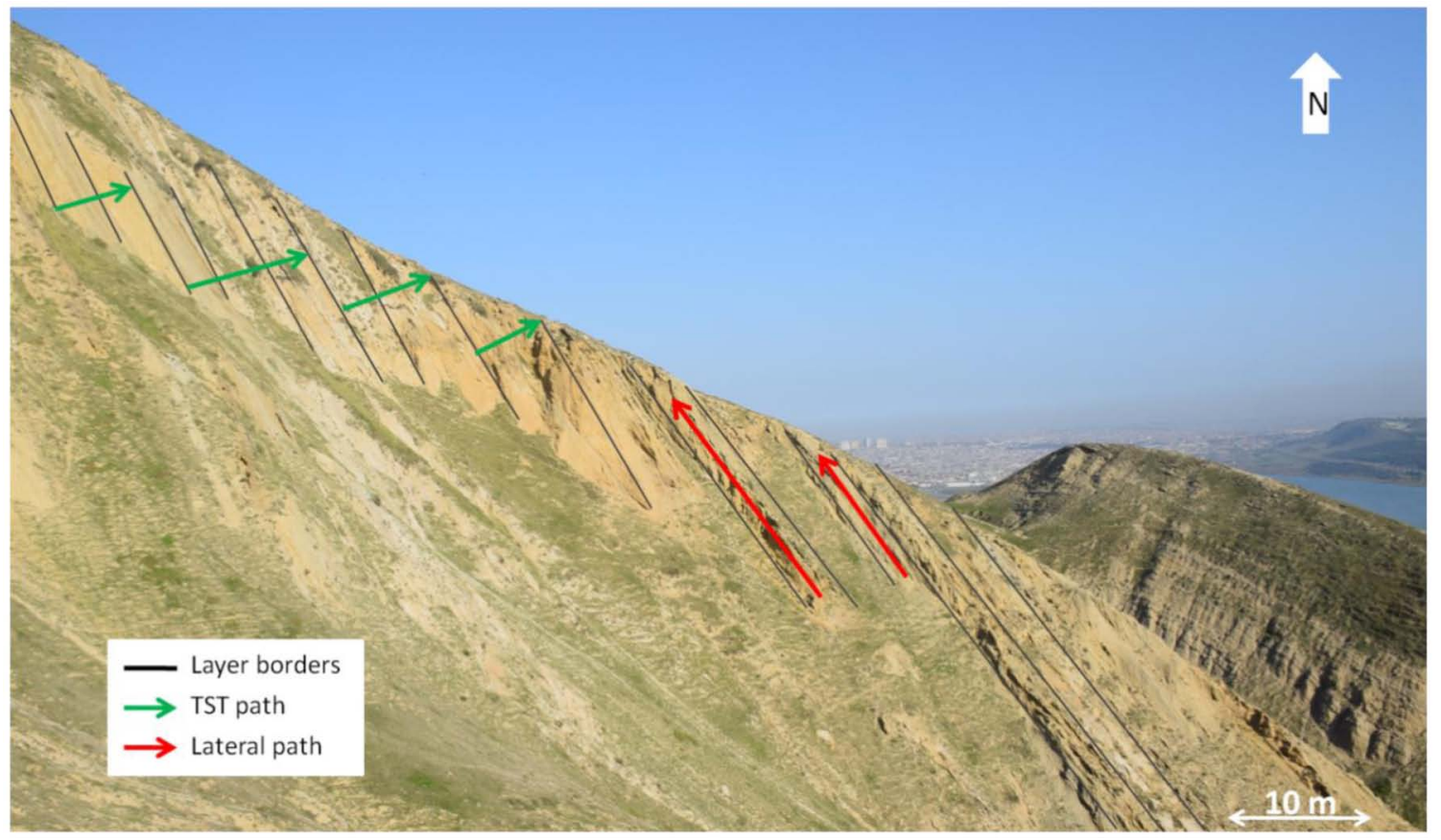

Figure 3.1-Schematic representation of field measurement paths: across the stratigraphy (green arrows) and along individual stratigraphic units (red arrows)

Tiny Perm II tool was used to measure air permeability of sandstones at same locations as stationary GR measurement points to keep corresponding values and conduct an integrated analysis of DB influence on reservoir properties. All measurements were accompanied by detailed facies and DB characteristics description, including their sizes and concentration per meter. Relations of DB concentration and $\mathrm{V}_{\text {shale }}$ to permeability were separately examined and compared to differentiate their impact. To investigate the effect of bed geometry on DB occurrence, dip and strike data of the layers under interest were collected using a Brunton compass.

On the contrary, the numerous influencing factors mentioned above obscure the understanding of fieldscale DB characteristics and their impact, thus certain cut-offs must be set to check for dominance of one factor over another in attempt to decrease the uncertainty. This was accomplished by gathering and analyzing data along single sandstone facies with minor variation in dips and shale volume, as illustrated with red arrows in Fig. 3.1, allowing for sensitivity analysis and more observable relations of DB concentration to permeability.

Field measurements alone (natural radioactivity and onsite permeability) are not sufficient for full evaluation of properties of the observed deformed rock units. Impact of DB was also studied on the microscale to look for their dependency on intrinsic rock properties based on merged analysis of thin section petrography and laboratory measurements such as RCAL, XRD, SEM and CT on samples acquired from Yasamal Valley. Because sampling procedure affects the following quality and interpretation of lab tests, sister plugs, one with and one without DB, were carefully cored at centimeter distance from each other to minimize any geologic dissimilarity (Fig. 3.2). 


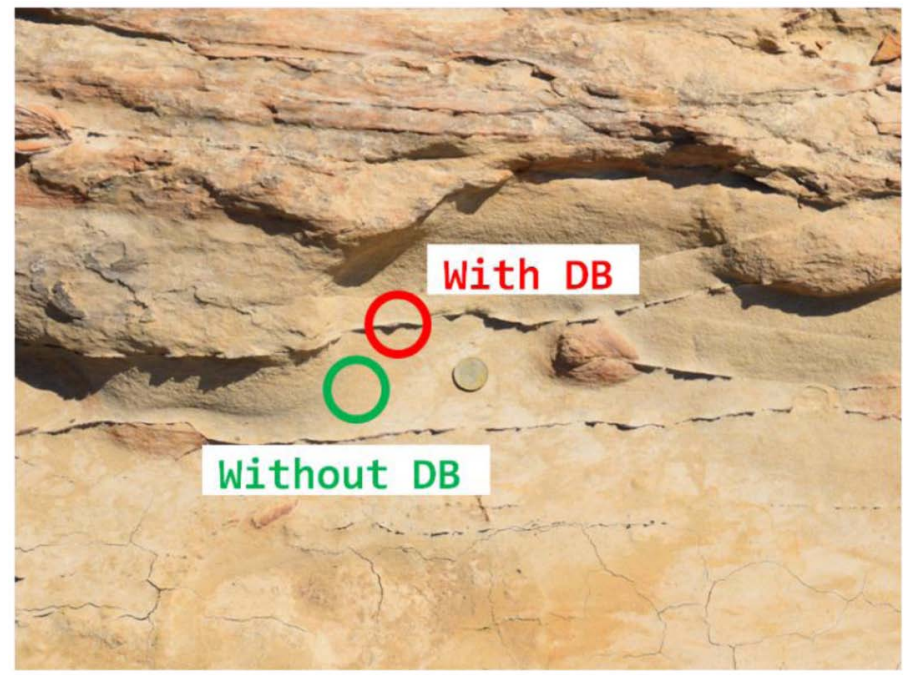

Figure 3.2-Sisterplugs with and without deformation bands taken 1-2 cm separate from each other

XRD measurements provide fractions of solid per mineral species (Fig. 10), which were used for initial validation of mineralogical identity of sister plugs and sandstone facies description and for further analysis of calcite and clay fractions impact on porosity and permeability of plugs without deformation bands. SEM images and thin sections were used to visualize the DB type and derive grain sizes, as one of the controlling factors of deformation mechanisms.

Helium porosimeter and air permeameter (at 400 psi confining pressure) were used to measure and compare porosity and permeability of sister plugs, accordingly. To quantify rock degradation, permeability contrast (taken as deterioration ratio) between DB and parent rock was also investigated. While several sophisticated numerical modeling techniques exist for estimation of single DB permeability, within the reach of our study we used a simple harmonic averaging methodology of serial beds (Ahmed, 2001), one of which was taken as a deformation band (Fig. 3.3). The analytical equation is defined as:

$$
K_{a v}=\frac{L_{t}}{\frac{L_{b}}{K_{b}}+\frac{\left(L_{t}-L_{b}\right)}{K_{h}}}
$$

where:

$\mathrm{K}_{\mathrm{av}}$ - average permeability of the plug with deformation band,

$\mathrm{L}_{\mathrm{t}}$ - total length of the plug,

$\mathrm{L}_{\mathrm{b}}$ - width of deformation band inside the plug,

$\mathrm{K}_{\mathrm{b}}$ - deformation band permeability,

$\mathrm{K}_{\mathrm{h}}$ - host rock (matrix) permeability (the plug without DB). 


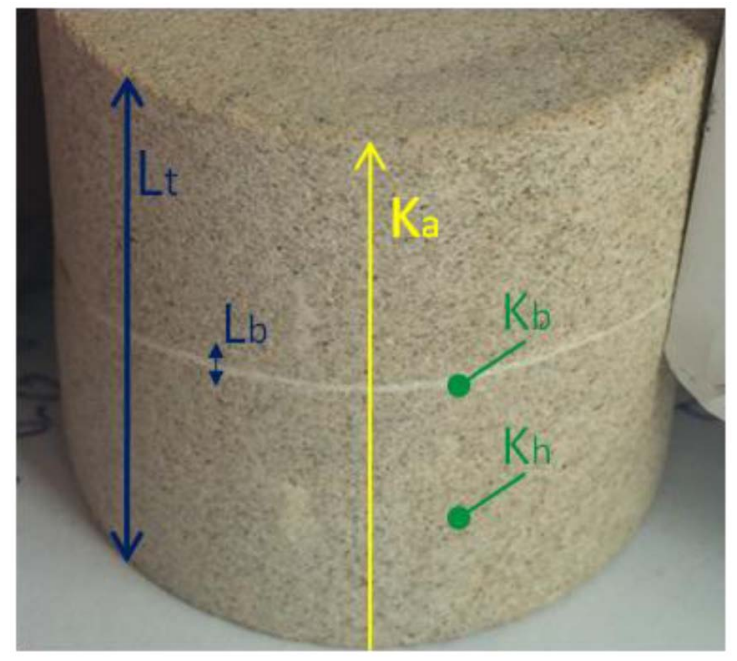

Figure 3.3-Inputs for calculation of single DB permeability on the example of a calcite-rich plug

\section{Results and Discussion}

This section is aimed at discussion of results obtained from integration of laboratory tests and field measurements to characterize creation of deformation bands and their impact on macro and micro scales. Here, we distinguish two concepts regarding prediction of DB: the number observed in a meter and their presence or absence only. We believe that one of several parameters controlling formation and absolute number of deformation bands may become dominant over another. Such tendency is observed in the Balakhany subunits of the Productive Series when estimated shale volume becomes greater than $18 \%$ for unconsolidated and $32 \%$ for consolidated, calcite-rich sandstones (Fig. 4.1). In the case these thresholds are met, no deformation bands occur in any given value of bed dip angle range (40-90 degrees). Additionally, rapid variation in strike also causes formation of deformation bands, which is out of the scope of this study. Brittleness and relatively weaker nature of calcite concretions abundant in consolidated sandstones led to the increase of the threshold value by almost a factor of two. This phenomenon is explained as following: the more calcite fraction in the rock, the more ductile minerals are required to compensate it. Non-uniform decline of DB occurrence and their frequencies for calcite-rich sandstones can be caused by variation of calcite percentage, which ranges between $38-48 \%$ based on XRD results (Fig. 2.10), with according Vshale value.
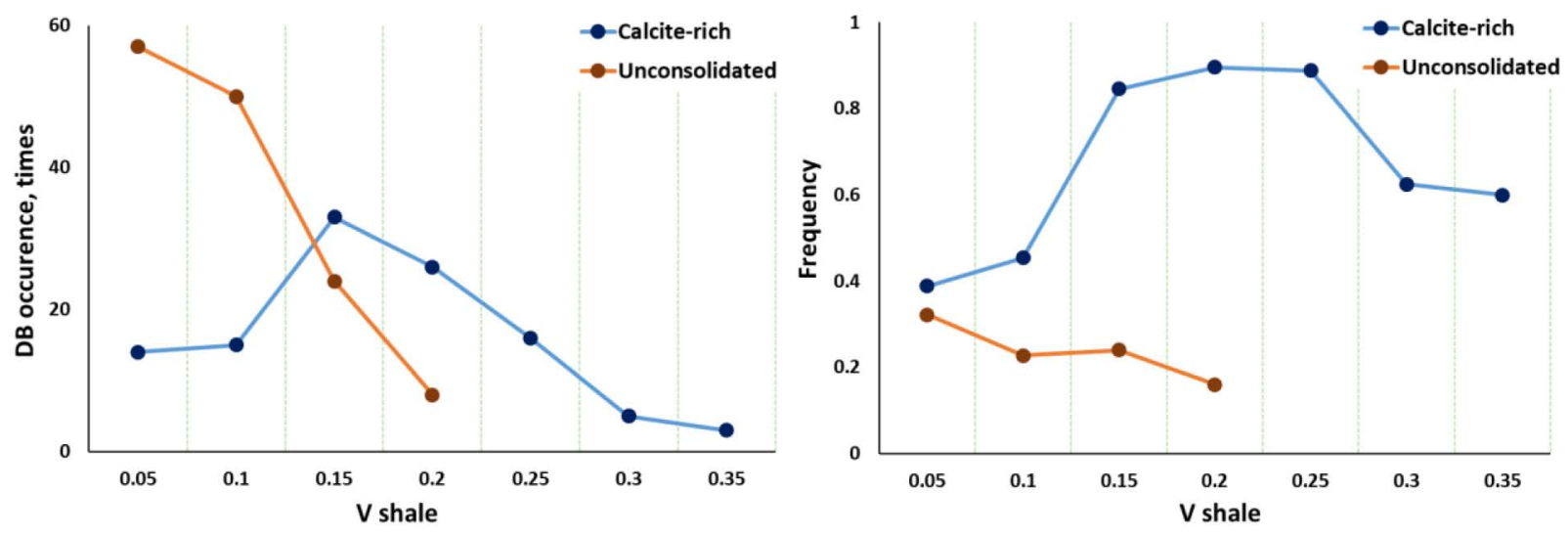

Figure 4.1-Relation of occurrence of deformation bands (left) and their frequencies (right) to shale volume

Prediction of number of deformation bands per meter as a function of one variable (e.g. V shale, dip angle) requires minimizing the fluctuation of other factors. Hence, to investigate control of dip angle 
individual sandstone layers with little change in shale volume are considered. The same methodology is set for quantification of DB number versus shale volume variation: individual layers with little dip angle change are examined. Both plots in Figure 4.2 show correlation with average number of bands in their $\mathrm{V}$ shale ranges. Applicability of these relations, either separately or combined, is a subjective task.
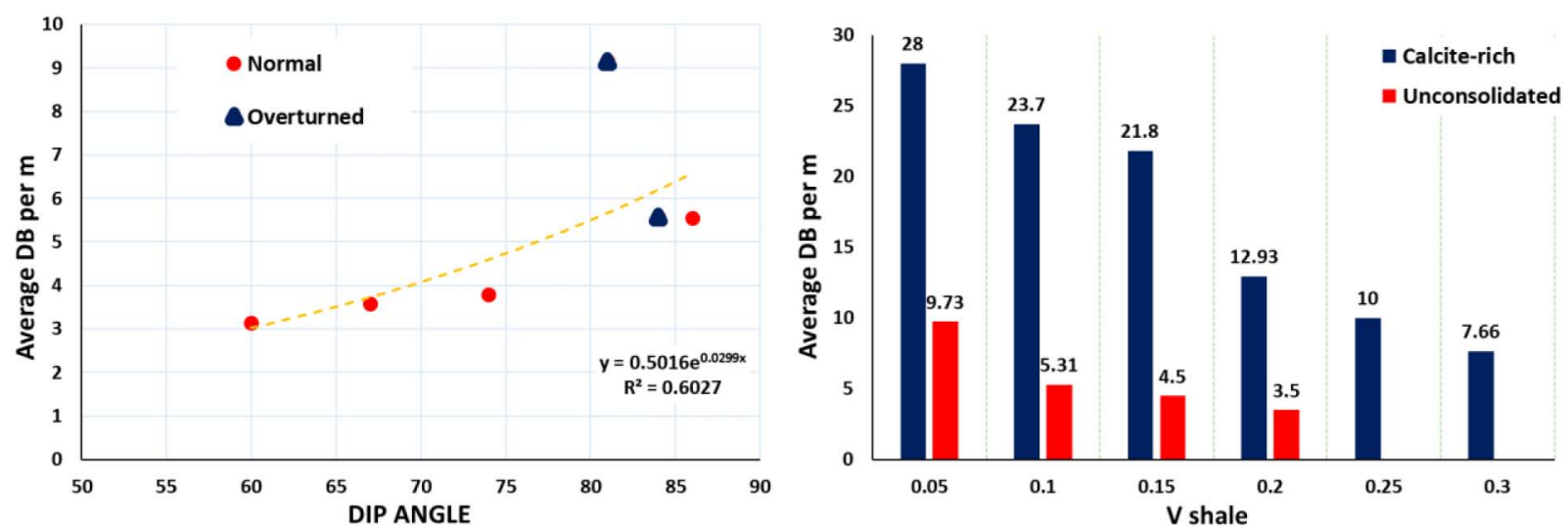

Figure 4.2-Relation of dip angle (left) and shale volume (right) to average number of deformation bands

Relationship between dip angle and DB counted perpendicular to bedding do not reveal an obvious correlation. Another outlook would be prediction based on dip or strike gradient, precise estimation of which requires sufficient number of measurements and variety of values along some distance, which was not observed during the study. Nevertheless, it is expected that the greater the gradient, the higher the concentration of DB until certain threshold value, after which several joints or faults will be formed in sandstones.

Criteria for formation of deformation bands from lithological perspective was examined using XRD test outcomes, as well. A sample taken from an unconsolidated sandstone unit of the Balakhany Suite without DB has total clay content of $21.3 \%$ (montmorillonite- $10.7 \%$, illite-5.2\% and kaolinite-5.4\%), which is in accordance with Vshale cut-off value (18\%). However, more samples are required to confirm this observation.

Representative scale for estimation of petrophysical properties has always been a vulnerable feature and needs careful consideration. Rock properties start to alter after formation of fold structures, where grain reorganization by sliding, rotation and/or cataclasis is among the main processes. Intensity of this process changes initial porosity and permeability in various degrees and leads to formation of small DB and large scale faults.

Quantification of field scale impact is probably more complicated due to heterogeneities of the Balakhany Suite and applied methodology. Field measurements allow juxtaposing effects of shale volume and DB concentration on permeability deterioration in sandstones. As can be seen from Fig. 4.3, exponential permeability decline constant for deformation bands is trice higher than for shale volume. 

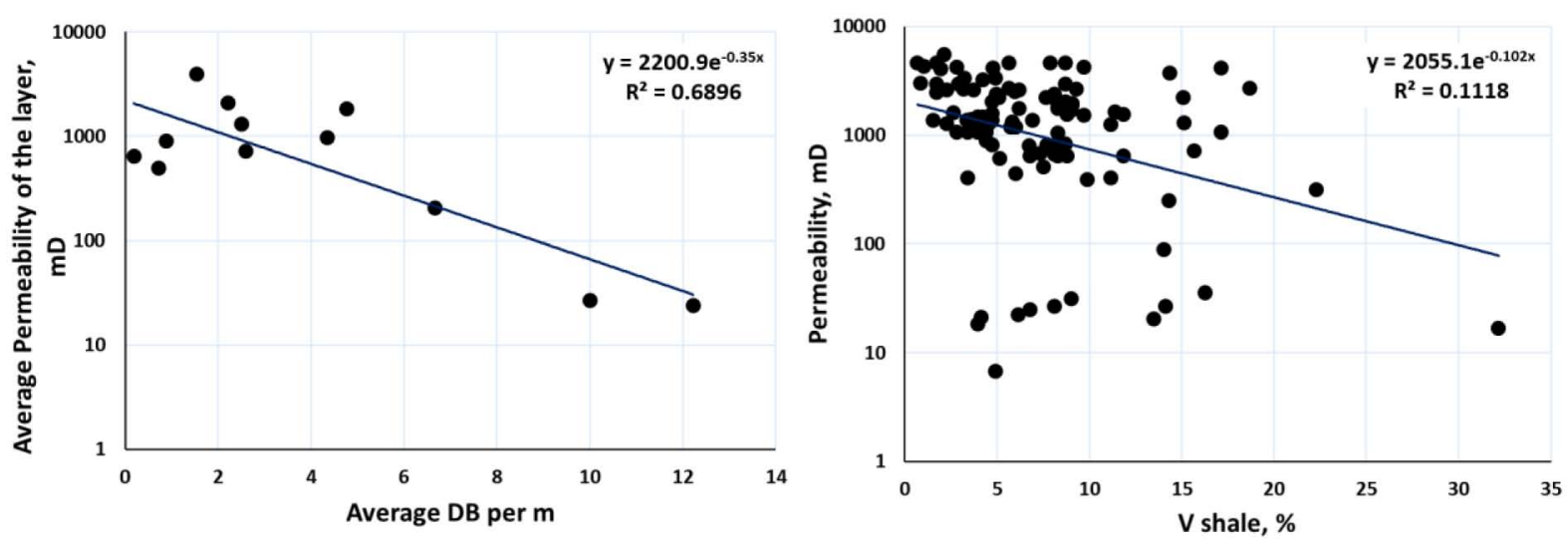

Figure 4.3-Field scale permeability dependency on DB number (left) and shale volume (right).

Relationship between average number of deformation bands and average permeability of sandstone layer indicates that property worsening is not only local but also takes place near deformation bands. The relationship shown for the Balakhany Suite could have an opposite effect if the petrographic features of sandstone units were different. For example, Fossen et al. (2011) observed an increase in number of deformation bands for coarse-grained sandstones with permeability reaching 80 Darcy. In contrast, sandstones observed by us are only very fine- to fine-grained.

So far, average DB concentration and permeability of layers were described. Fig. 4.4 shows relations of absolute DB number and permeability in two individual layers - Balakhany VI (B6) and VIII (B8) subunits. Permeability decrease is well aligned with increased number of bands between positions 20 and 30 for B6 layer. This logic remains roughly at positions 30 - 45 with slight deviations.
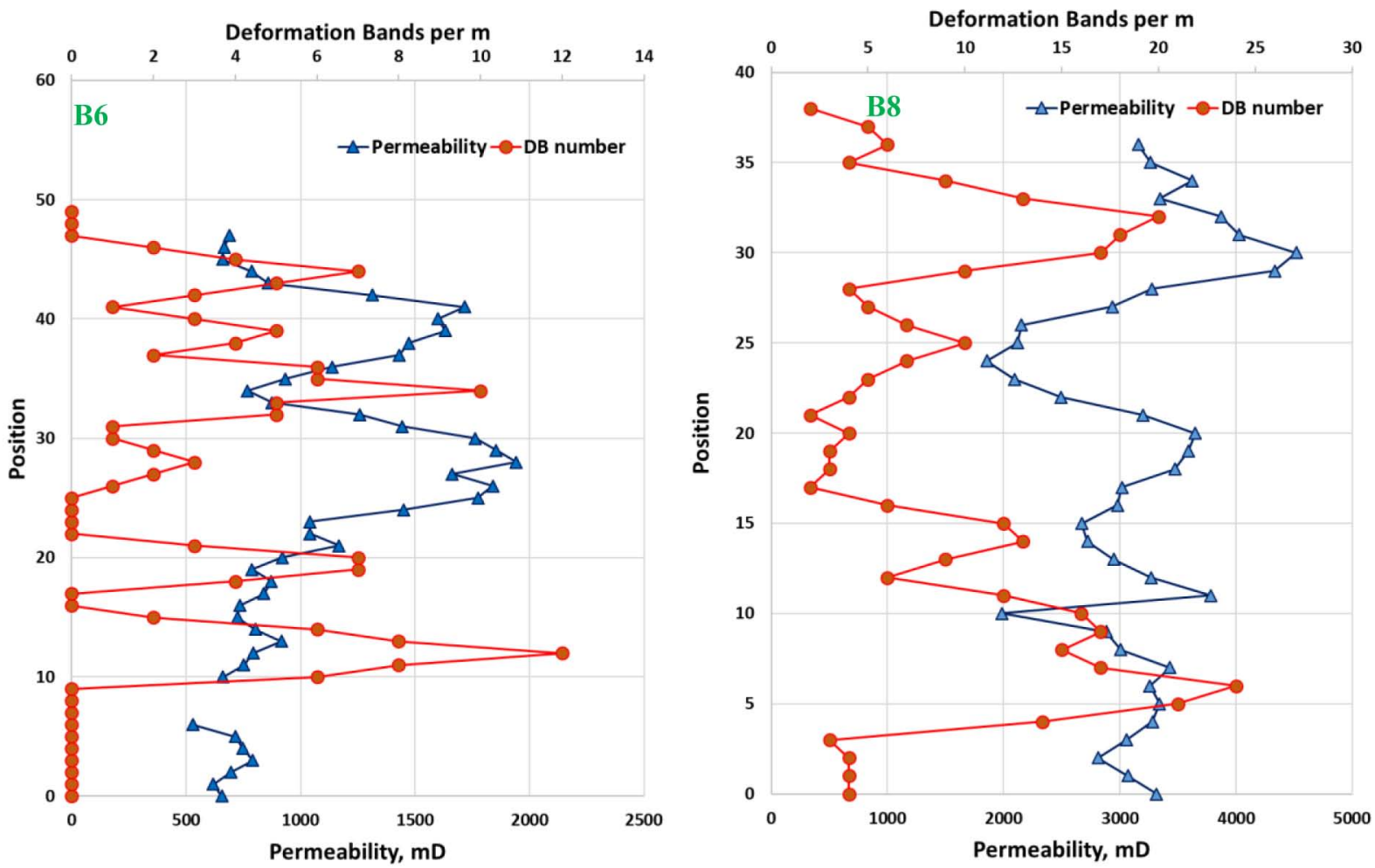

Figure 4.4-Juxtaposition of absolute DB number and permeability measured on individual sandstone layers of Balakhany VI (B6, left) and VIII (B8, right) subunits. 
Such relationship remains true for B8 layer at positions 10-28. On the other hand, anomalous permeability increase has been observed in the regions 1-10 and 28-35, which is possibly related to lithological and petrophysical heterogeneity of the layer.

Micro-scale effect was quantified via analysis of tests on two sister plugs with and without DB, porosity and permeability of which are compared in Fig. 4.5.
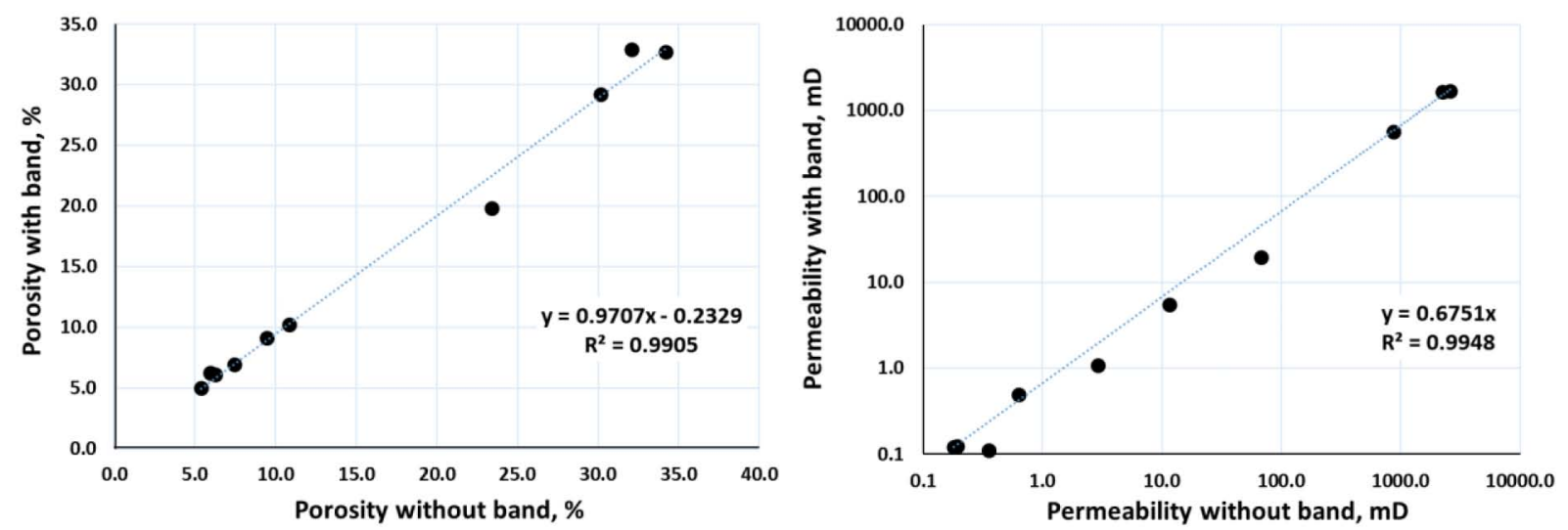

Figure 4.5-Comparison ofporosity (left) and permeability (right) of sister plugs from Yasamal Valley

Relationships in Fig. 4.5 show that porosity is deteriorated by 3\% from parent rock value, which led to $33 \%$ decrease in permeability. Deformation band, having a small bulk volume fraction of the plug (i.e. less porosity decline rate), behaves as a barrier where collapse of pore throats inside it leads to stronger capillary threshold value. Relationships between porosity and permeability of non-deformed sandstones can be modified using this finding, accordingly.

The plugs without DB were also used to study the effects of calcite and clay fractions on reservoir properties and compare them to aforementioned field- and micro-scale impact of DB. Measurements in these sandstone plugs show a sharp reduction of porosity and permeability with the increase of pore-filling calcite and clay fractions (Fig. 4.6). Moreover, clays show a greater impact on permeability: e.g. with $15 \%$ of calcite and total clay, permeability is reduced to $207 \mathrm{mD}$ and $44 \mathrm{mD}$, respectively (refer to dashed lines in Fig. 4.6 (b) and (d)). A possible explanation for this is that calcite concretions are subject to dissolution and formation of secondary porosity, while clays are more cohesive and can fill into pore throats. As can be seen from Fig. 4.3 (left) and Fig 4.6 (b \& d), exponential permeability decline constants for calcite and clay fractions are slightly higher than for average DB number. In the case of micro-scale influence comparison, permeability reduction by a single DB from Fig. 4.5 shows a linear decline rate of $33 \%$, while for calcite and clay fractions this decline is exponential. 

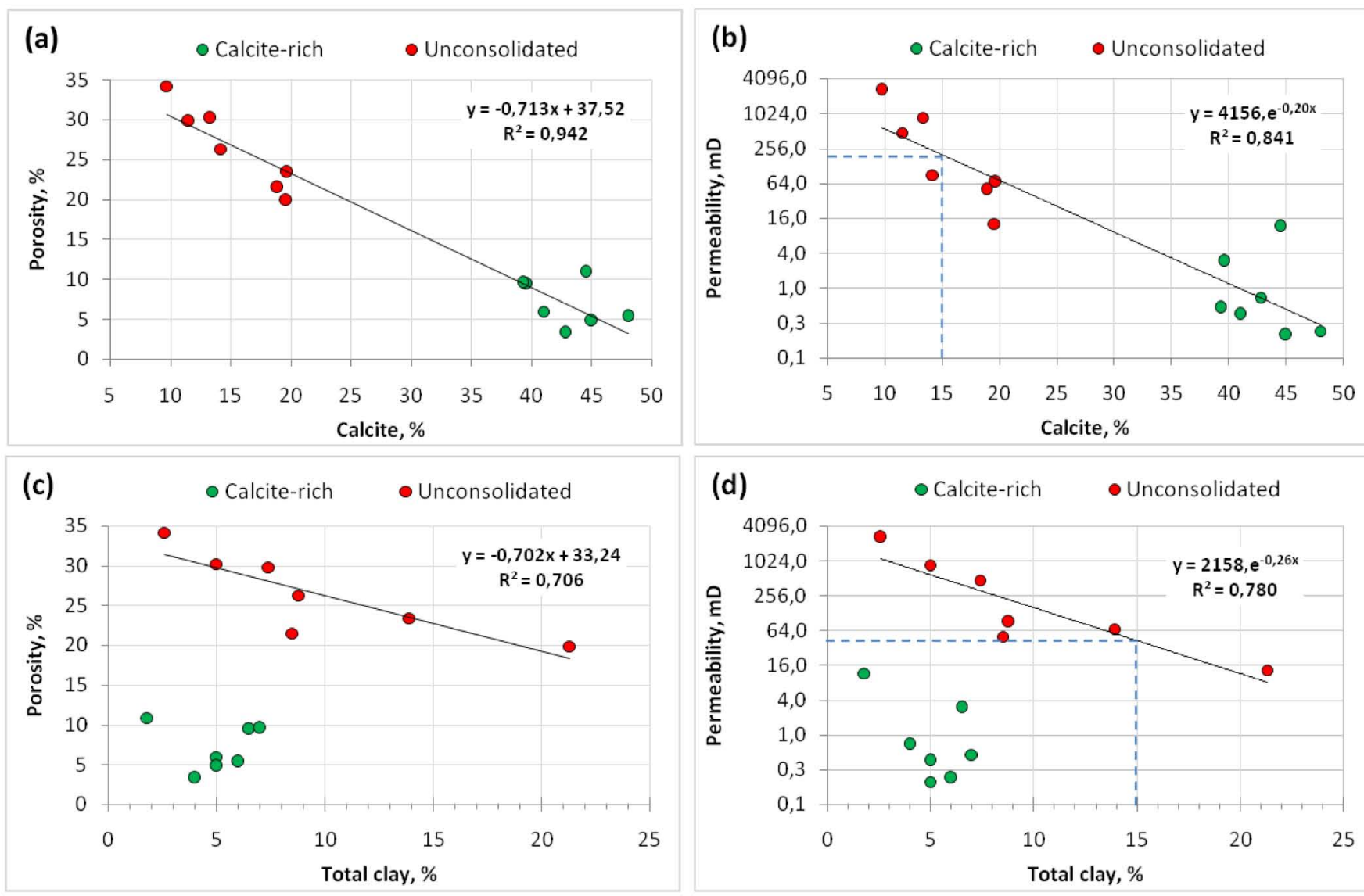

Figure 4.6-(a) and (b) - impact of calcite fraction on porosity and permeability, (c) and (d) - impact of clay fraction (total of illite, montmorillonite and smectite fractions) on porosity and permeability of sandstones without DB.

Having established permeability of a single deformation band using harmonic averaging technique, deterioration ratio is estimated as:

$$
\text { Ratio }=\frac{K_{\text {host rock }}}{K_{\text {band }}}
$$

Deterioration ratio has been analyzed as a function of initial rock permeability. Most of the data in Fig. 4.7 show that the more permeable the host rock, the less the deterioration caused by a single band. The assumption imposed here is little variation of compaction and shear forces applied on these samples. Amount of cement crushed during formation of deformation bands creates an extra effect on resultant permeability.

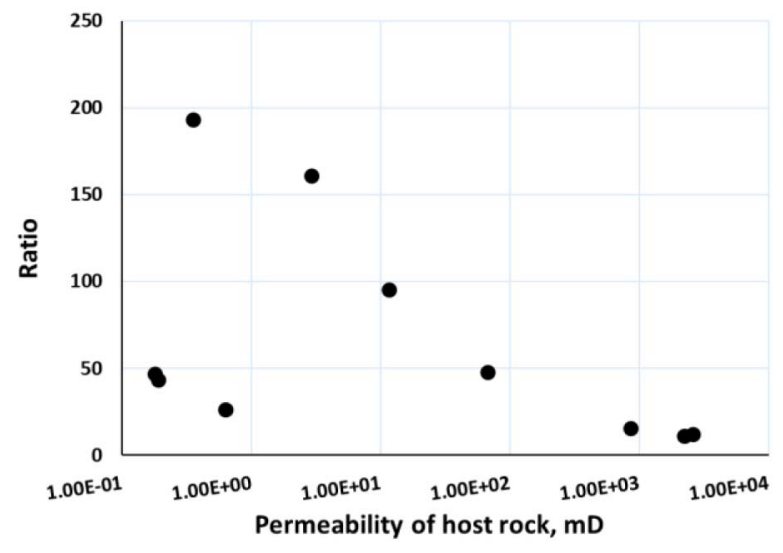

Figure 4.7-Permeability deterioration (defined as ratio) by individual DB 


\section{Conclusion}

Successions of sandstone and mudstone-shale dominated facies of Balakhany units characterize repeated proximal and distal fluvial, and tidal-deltaic environments to high frequency base-level fluctuations of Caspian lake, which caused the high volume of calcite cement precipitation in fluvial-deltaic channelized sandstone observed in Yasamal Valley. Calcite-rich sandstones are interpreted to be possible deposits of a tide-influenced delta, since sandstone bodies have gradational bases and sharp contacts with overlying mudstones. Beds record deposition of sands during delta-front progradation, followed by the more gradual aggradation of mudstones and tidal reworking. Isotopic analysis is recommended to be performed for the reliable interpretation of the calcite cement origin and the timing of its precipitation.

Characterization of rock properties in deformed areas is complicated by several factors that either counteract or enhance each other. Integration of field and laboratory results reveal appropriate model for prediction of deformation bands as a function of shale volume for Balakhany sandstones. Threshold values (18\% and 32\%) set for unconsolidated and calcite-rich sandstones are among valuable inputs for prediction of deformation bands. Field observations suggest that ductility caused by high shale volumes make DB occurrence less dependent on formation dip angle. Field observations suggest modeling of clay content influence on deformation mechanism as future work. Similar analysis involving DB count versus dip gradient might yield better results. More data on DB count is required for proper representation of average number of deformation bands, which cannot always be achieved when measuring in the direction perpendicular to layering. Additional investigations are required for incorporation of lithological and structural effects.

Permeability reduction in deformation bands is up to 200 times based on laboratory results. The average decrease in porosity caused by DB presence is not as significant as for permeability. Moreover, rock samples with lower permeability of the host rock demonstrate greater permeability reduction induced by the DB. Results of field measurements imply that influence of deformation band upon rock properties extends slightly away from its plane. This idea is supported by the observed reduction of permeability in the regions with relatively high population of DBs.

Effects of deformation bands were quantified separately for field and plug scales. Core flooding experiments upon samples with different number of deformation bands from a single sandstone layer could enhance the upscaling of the pore scale measurements. This may improve the understanding of spatial influence of DBs on rock properties.

\section{Acknowledgments}

The authors would like to thank all member companies of Azerbaijan International Operating Company (AIOC) for funding this study and BP Exploration Ltd. for their support.

\section{References}

Alburki, A.A.,2015. Aspects of the tectonics of the Greater Caucasus and Western South Caspian Basin, Durham theses, Durham University.

Allen, M. B., S. J. Vincent, G. I. Alsop, A. Ismail-zadeh, and R. Flecker. 2003. Late Cenozoic deformation in the South Caspian region: Effects of a rigid basement block within a collision zone: Tectonophysics, v. 366, p. 223-239.

Allen, M. B., Jackson, J., Walker, R., 2004. Late Cenozoic reorganization of the Arabia-Eurasia collision and the comparison of short-term and long-term deformation rates. TECTONICS, VOL. 23, TC2008.

Alizadeh, A.A., Akhmedov, G.A., Akhmedov, A.M., Aliyev, A.K., Zeynalov M.M. 1966. Geology of oil and gas fields of Azerbaijan. Nedra, Moscow, 283-288 p.

Asquith, G., Krygowski, D. 2004. Basic Well Log Analysis: AAPG Methods in Exploration 16, p.31-35

Aydin, A. 1978. Small faults formed as deformation bands in sandstone. Pure and Applied Geophysics, 116, 913-930.

Aliyeva, E. 2005. Reservoirs of the Lower Pliocene Productive Series at the Western Flank of the South Caspian Basin. Lithology and Mineral Resources, Vol. 40, No. 3, 2005, pp. 267-278. 
Ballas, G., Fossen, H., Soliva, R. 2015. Factors controlling permeability of cataclastic deformation bands and faults in porous sandstone reservoirs. Journal of Structural Geology, 76, 1-21.

Brunet, M.F., Korotaev, M.V., Ershov, A.V., Nikishin, A.M. 2003. The South Caspian basin: a review of its evolution from subsidence modelling. In: Brunet, M.-F., Cloetingh, S. (Eds.), Integrated Peri-Tethyan Basins Studies (Peri-Tethys Programme). Sedimentary Geology 156, 119-148.

Devlin W. J., Cogswell J. M., Gaskins G. M., Isaksen G. H., Pitcher D. M., Puls D. P., Stanley K. O. 1999. South Caspian Basin: Young, Cool, and Full of Promise

Fossen, H., Bale, A. 2007. Deformation bands and their influence on fluid flow. AAPG Bulletin, v. 91, no. 12 (December 2007), pp. 1685-1700

Fossen, H., Schultz, R.A., Torabi, A. 2011. Conditions and implications for compaction band formation in the Navajo Sandstone, Utah. Journal of Structural Geology 33 (2011) 1477 - 1490.

Golonka, J., 2004, Plate tectonic evolution of the southern margin of Eurasia in the Mesozoic and Cenozoic: Tectonophysics, v. 381, no. 1-4, p. 235-273.

Green, T., Abdullayev, N., Hossack, J., Riley, G., Roberts, A. M. 2009. Sedimentation and subsidence in the South Caspian Basin, Azerbaijan: Geological Society, London, Special Publications, v. 312 p. 241 - 260.

Gurevich, A. E.,, Chilingar, G., V. 1995. Abnormal pressures in Azerbaijan: A brief critical review and recommendations: Journal of Petroleum Science and Engineering, v. 13, no. 2, p. 125-135.

Hempton, M.R., 1987. Constraints on Arabian plate motion and extensional history of the Red Sea. Tectonics 6, $687-705$.

Hinds, D.J., Aliyeva, E., Allen, M.B., Davies, C.E., Kroonenberg, S.B., Simmons, M.D., Vincent, S.J. 2004. Sedimentation in a discharge dominated fluvial-lacustrine system: the Neogene Productive Series of the South Caspian Basin, Azerbaijan. Marine Petroleum Geology, 21, 613-638.

Jackson, J., and Mckenzie, D., 1984, Active Tectonics of the Alpine Himalayan Belt between Western Turkey and Pakistan: Geophysical Journal of the Royal Astronomical Society, v. 77, no. 1, p. 185.

Jackson, J., Priestley, K., Allen, M., Berberian, M. 2002. Active tectonics of the South Caspian Basin. Geophysical Journal International 148, 214-245.

Jones, R. W., Simmons, M. D. 1996. A review of the stratigraphy of Eastern Paratethys (Oligocene-Holocene): Bulletin of the Natural History Museum London (Geology), v. 52, p. 25-49.

Morton, A., Allen, M., Simmons, M., Spathopoulos, F., Still, J., Hinds, D., Ismail-Zadeh, A., and Kroonenberg, S. 2003. Provenance patterns in a neotectonic basin: Pliocene and Quaternary sediment supply to the South Caspian, Basin Research, 15, 321-337

Nemčok, M., Feyzullayev, A. A., Kadirov, F.A., Zeynalov, G.A., Allen, R., Christensen, C., and Welker, B. 2011. Neotectonics of the Caucasus and Kura Valley, Azerbaijan, "Global Engineers and Technologist Review " journal, Vol.1, No 1, Malaysia, pp.1-14

Reynolds, A. D., Simmons, M. D., Bowman, M. B. J., Henton, J., Brayshaw, A. C., 4, Ali-Zade, A. A., Guliyev, I. S., Suleymanova, S. F., Ateava, E. Z., Mamedova, D. N., Koshkarly, R. O. 1998. Implication of outcrop geology for reservoirs in the Neogene, Apsheron Peninsula, Azerbaijan AAPG Bulletin v. 82, p. 25-49.

Rønnevik, C. 2013. Low-temperature thermochronology apatite fission-track (AFT) study and structural relations associated with the Uncompahgre Plateau and Paradox Basin area, Utah and Colorado, USA. Master's thesis, Department of Earth Science, University of Bergen.

Schultz, R.A., Siddharthan, R. 2005. A general framework for the occurrence and faulting of deformation bands in porous granular rocks. Tectonophysics 411 (2005) 1 - 18.

Zuluaga, L.F., Fossen, H., Rotevatn, A. 2012. Structural reservoir heterogeneity induced by forced folding in sandstone reservoirs: the San Rafael Reef Monocline, Utah, USA. The Geological Society (Petroleum Group/Tectonic Studies Group Conference), London, 28-30 November 2012.

Zonenshain, L. P., Pichon, X. 1986. Deep basins of the Black Sea and Caspian Sea as remnants of Mesozoic back-arc basins: Tectonophysics, v. 123, no. 1-4, p.181-211. 